\title{
DESAIN DAN UJI COBA E-MODUL PEMBELAJARAN KIMIA BERBASIS BLOG PADA MATERI HIDROKARBON
}

\author{
Novita Septryanesti ${ }^{1^{*}}$ dan Lazulva ${ }^{1}$ \\ ${ }^{1}$ Program Studi Pendidikan Kimia, Fakultas Tarbiyah dan Keguruan, Universitas Islam Negeri \\ Sultan Syarif Kasim Riau, Kampus II Raja Ali Haji. Jl. H. R. Soebrantas Km. 15 Tampan, \\ Pekanbaru, 28293, Indonesia \\ *E-mail: septryanesti@gmail.com
}

\begin{abstract}
ABSTRAK
Penelitian ini bertujuan untuk mengetahui tingkat validitas dan praktikalitas e-modul pembelajaran kimia berbasis blog pada materi hidrokarbon. Penelitian ini merupakan jenis penelitian dan pengembangan atau $R$ \& $D$ dengan menggunakan model Borg \& Gall yang terdiri dari 10 tahap, namun penelitian ini terbatas sampai pada tahap ke 5 . Subjek dalam penelitian ini adalah ahli materi, ahli media, guru kimia dan siswa kelas XII TKJ 2 SMK Pekanbaru. Objek penelitian ini adalah e-modul pembelajaran kimia berbasis blog pada materi hidrokarbon. Teknik pengumpulan data diperoleh dari angket uji validitas, uji praktikalitas, uji respon siswa, wawancara, dan dokumentasi. Analisis data dilakukan dengan teknik analisis deskriptif kualitatif dan deskriptif kuantitatif. Hasil penelitian menunjukkan tingkat validitas $e$-modul pembelajaran kimia diperoleh sebesar 90,5\% (sangat valid), tingkat praktikalitas diperoleh sebesar 95,2\% (sangat praktis) dan respon siswa diperoleh sebesar $87,2 \%$ (sangat baik). Dari hasil tersebut mengidentifikasikan bahwa e-modul pembelajaran kimia berbasis blog pada materi hidrokarbon yang diujicobakan layak dan praktis sebagai sumber belajar mandiri di sekolah.
\end{abstract}

Kata kunci: blog, e-modul, hidrokarbon

\begin{abstract}
This research aimed at knowing validity and practicality levels of the Blog based e-module that was valid and practical. It was a R\&D with Borg and Gall model. The subjects of this research were 2 material expert lecturers, a media expert lecturer, 2 Chemistry subject teacher, and 10 students Vocational Pekanbaru High School. The object was Blog based e-module on Hydrocarbon Chemistry subject lesson. The collecting technique the data were validity test questionnaire, practicality, student response, interview, and documentation. Analyzing data was done by using Descriptive qualitative and quantitative. The research findings showed that the validity level of the e-module was $90.5 \%$ (very valid), the practicality level was $95.2 \%$ (very practical), the student percentage response to e-module was $87.2 \%$ (very good). Based on these results, it could be identified that Blog based e-module on Hydrocarbon Chemistry subject lesson was appropriate and practical to be learning source at school.
\end{abstract}

Keywords: blog, e-module, hydrocarbon

DOI: http://doi.org/10.15575/jtk.v4i2.5659 

Hidrokarbon

\section{PENDAHULUAN}

Belajar merupakan proses perubahan tingkah laku sebagai hasil dari interaksi seseorang dengan lingkungannya. Perubahan tingkah laku yang dimaksud dapat berupa perubahan berkaitan dengan penambahan kemampuan berpikir, kemampuan bersikap. Keberhasilan proses belajar dipengaruhi oleh banyak faktor, baik faktor internal maupun faktor eksternal. Faktor internal adalah faktor yang berasal dari dalam diri siswa antara lain motivasi, minat, dan kemampuan berpikir siswa. Faktor eksternal adalah faktor yang berasal dari luar, antara lain lingkungan belajar, keluarga, masyarakat dan sekolah. Faktor sekolah meliputi kurikulum, metode mengajar, relasi antara siswa dengan guru maupun siswa dengan siswa, dan alat pelajaran (Priyayi, 2016).

Faktor-faktor yang mempengaruhi pelaksanaan pembelajaran di sekolah diantaranya cara guru menyampaikan pembelajaran, suasana kelas (lingkungan belajar), bahan ajar yang digunakan, dan sebagainya. Bahan ajar memiliki arti yang penting bagi guru maupun siswa dalam kegiatan pembelajaran. Guru akan mengalami kesulitan dalam meningkatkan efektivitas pembelajaran apabila tidak mempunyai bahan ajar yang lengkap. Di samping itu, tanpa adanya bahan ajar, siswa juga akan mengalami kesulitan dalam belajarnya (Rahmi dkk., 2014).

Bahan ajar adalah bahan atau materi pelajaran yang disusun secara lengkap dan sistematis berdasarkan prinsip-prinsip pembelajaran yang digunakan guru dan siswa dalam proses pembelajaran. Modul merupakan bahan ajar yang ditulis dengan tujuan agar siswa dapat belajar secara mandiri tanpa atau dengan bimbingan guru. Modul berisi tentang petunjuk belajar, kompetensi yang dicapai, isi materi, informasi pendukung, latihan soal, evaluasi, dan balikan hasil evaluasi (Rahmi dkk., 2014).

Namun kenyataannya modul yang ada di sekolah masih dalam bentuk konvensional atau cetak sehingga hanya dapat menampilkan gambar dalam bentuk dua dimensi. Modul yang selama ini digunakan dalam proses pembelajaran masih memiliki layout sederhana dan isi yang hanya berupa materi pokok saja. Modul seperti ini membuat siswa cenderung merasa bosan dalam mempelajari materi pada setiap pokok bahasan sehingga diperlukan suatu pengembangan media pembelajaran berupa modul yang dapat menarik minat siswa pada materi kimia (Sari dkk., 2014).

Oleh sebab itu, untuk meningkatkan mutu pendidikan yaitu dengan menyediakan bahan ajar yang mudah diperoleh, mudah dimengerti dan menarik minat pembaca seperti modul elektronik dengan memanfaatkan perkembangan teknologi. Pembelajaran dengan modul elektronik dapat dilakukan melalui media internet, macromedia flash, java, maupun media elektronik lainnya. Pembelajaran seperti ini dikenal dengan sebutan elektronik learning (e-learning) membawa pengaruh terjadinya proses transformasi pendidikan konvensional ke dalam bentuk digital, baik secara isi ataupun sistemnya (Zulkarnain dkk., 2015).

Blog sebagai salah satu layanan aplikasi dari internet dapat dimanfaatkan oleh guru dan siswa sebagai sumber belajar yang tidak terbatas. Guru dapat mengunggah semua informasi yang berkaitan dengan materi pembelajaran yang diajarkan dengan menambahkan multimedia (gambar, animasi, efek suara dan video) agar menarik dan lebih mudah dipelajari. Dilihat dari sisi siswa, siswa dapat mengunduh informasi yang sesuai 
dengan topik dan tujuan yang diinginkan. Penggunaan blog sebagai media pembelajaran sekaligus sebagai sumber belajar paling tidak akan mengubah cara belajar dan teknik pembelajaran agar tidak monoton sehingga dapat memotivasi siswa dalam mempelajari sesuatu (Sartono, 2016).

Kimia merupakan mata pelajaran ilmu pengetahuan alam yang cukup sulit untuk dipahami. Salah satu materi pokok kimia yang dianggap sulit adalah materi hidrokarbon. Materi ini membutuhkan pemahaman konsep yang kuat dan bersifat komprehensif. Dalam materi hidrokarbon siswa dituntut untuk dapat mengenal hidrokarbon, mengetahui tata nama hidrokarbon, isomer, serta sifat dan kegunaan hidrokarbon dalam kehidupan sehari-hari (Agustina dkk., 2013).

Oleh karena itu, perlu dilakukan pengembangan bahan ajar berupa e-modul yang dapat membantu siswa dalam memahami konsep pada materi hidrokarbon. Pada e-modul ini konsep hidrokarbon akan dijelaskan dengan bahasa yang sederhana. Tata cara penamaan hidrokarbon juga akan diuraikan secara bertahap sehingga akan memudahkan siswa untuk mengikuti tahapan tersebut. Penyampaian materi hidrokarbon dalam proses belajar mengajar yang menarik akan dapat mengubah kimia yang sulit menjadi kimia yang menyenangkan.

Berdasarkan studi awal yang telah dilakukan di SMK Pekanbaru, sumber belajar yang digunakan berupa buku teks pelajaran. Ketersediaan buku teks pelajaran kimia yang terbatas dan dengan sistem rolling ke setiap kelas mengharuskan siswa menggunakan buku teks pada saat pembelajaran kimia saja. Sehingga siswa kurang memahami materi pelajaran yang disampaikan. Adanya sarana dan prasarana di SMK Pekanbaru yang memadai yaitu gedung dan ruang kelas yang nyaman, ruang media dengan fasilitas peralatan multimedia seperti komputer TV Out (LCD) dan jaringan internet yang dapat diakses di seluruh lingkungan sekolah merupakan faktor yang mendukung guru dalam penerapan e-modul berupa blog dalam pembelajaran kimia. e-modul kimia berbasis blog memiliki keuntungan bagi siswa yaitu siswa dapat dengan mudah mengunduhnya tanpa dibatasi ruang dan waktu. Dengan cara ini tentunya dapat menghemat waktu, tenaga dan biaya.

Kelebihan dan kemudahan dalam membuat blog ini dapat dimanfaatkan oleh guru untuk menciptakan suatu media pembelajaran yang menarik dan inovatif sehingga siswa dapat dengan mudah menggunakan media ini sebagai media pembelajaran mandiri yang dapat digunakan sewaktu-waktu tanpa dibatasi ruang dan waktu. Guru dapat membagi semua informasi yang berkaitan dengan materi pembelajaran yang diajarkan dengan menambahkan multimedia (gambar, animasi, efek suara, dan sebagainya) agar siswa lebih tertarik mempelajarinya. Melalui blog siswa dapat dengan mudah mengunduh materi atau informasi yang sesuai dengan topik dan tujuan yang diinginkan. Adanya $e$ modul berupa blog dapat memberikan variasi dalam melakukan kegiatan pembelajaran. Seorang guru tidak harus selalu memberikan materi pelajaran yang mungkin membosankan (Sari dkk., 2014).

Berdasarkan latar belakang yang telah diuraikan, maka tujuan dilakukan penelitian ini adalah untuk menghasilkan produk berupa e-modul pembelajaran kimia berbasis blog pada materi hidrokarbon yang valid dan praktis. 


\section{METODE PENELITIAN}

Penelitian ini termasuk ke dalam jenis penelitian pengembangan atau Research and Development ( $R$ \& $D)$ (Sugiyono, 2014). Desain e-modul pembelajaran kimia berbasis blog ini menggunakan model Borg \& Gall yang terdiri dari 10 tahap penelitian dan pengembangan, yaitu: 1) riset dan pengumpulan informasi, 2) perencanaan, 3) pengembangan produk awal, 4) uji lapangan produk awal, 5) revisi produk awal, 6) uji lapangan produk dalam skala yang lebih luas, 7) revisi produk, 8) uji lapangan pada skala yang lebih luas, 9) revisi akhir produk berdasarkan hasil analisis data pada uji lapangan akhir, dan 10) desiminasi dan melaporkan produk akhir hasil penelitian dan pengembangan (W. Sanjaya, 2013). Namun penelitian ini terbatas sampai pada tahap ke 5 ,

yaitu: revisi produk berdasarkan hasil uji lapangan produk awal.

Penelitian ini dilaksanakan pada semester ganjil tahun ajaran 2018/2019 pada salah satu SMK di Pekanbaru. Waktu pengambilan data mulai dari bulan Agustus sampai November 2018. Subjek dalam penelitian ini adalah validator dan responden. Validator terdiri dari 2 dosen ahli materi pembelajaran, 1 dosen ahli media pembelajaran, dan 2 guru kimia. Sedangkan responden terdiri dari 10 siswa kelas XII TKJ 2. Sedangkan objek dalam penelitian ini adalah e-modul pembelajaran kimia berbasis blog pada materi hidrokarbon.

Teknik pengumpuan data terdiri dari (1) wawancara, peneliti melakukan jenis wawancara tidak terstruktur dengan guru bidang studi kimia untuk menentukan kendala atau permasalahan yang dialami di sekolah. (2) Angket, angket yang digunakan disusun berdasarkan skala likert, diantaranya berupa angket uji validitas oleh ahli materi dan ahli media pembelajaran, angket uji praktikalitas oleh guru, dan angket respon siswa. (3) Dokumentasi, dokumentasi dalam penelitian ini berupa data yang mendukung penelitian lainnya.

Tabel 1. Skala Angket Penelitian

\begin{tabular}{|c|c|}
\hline Jawaban Item Instrumen & Skor \\
\hline Sangat baik & 5 \\
\hline Baik & 4 \\
\hline Cukup baik & 3 \\
\hline Kurang baik & 2 \\
\hline Tidak baik & 1 \\
\hline
\end{tabular}

Teknik analisis data yang digunakan adalah teknik analisis data deskriptif kualitatif dan teknik analisis deskriptif kuantitatif. Analisis deskriptif kualitatif dilakukan dengan cara menganalisis data kualitatif yang berbentuk kata-kata, bukan dalam bentuk angka (Trianto, 2010). Teknik analisis deskriptif kualitatif digunakan untuk mengolah data hasil penilaian berupa komentar dan saran oleh validator dan responden yang kemudian dianalisis secara deskriptif. Sedangkan Analisis deskriptif kuantitatif dilakukan dengan cara menganalisis data kuantitatif berupa angka atau bilangan (Trianto, 2010). Teknik analisis deskriptif kuantitatif digunakan untuk menganalisis data hasil penilaian angket oleh validator dan responden.

Untuk melakukan analisis deskriptif kualitatif e-modul yang dikembangkan digunakan skala likert dan diperoleh dengan cara (Riduwan, 2007):

1) Menentukan skor maksimal ideal

Skor maksimal ideal $=$ jumlah butir komponen $\times$ skor maksimal.

2) Menentukan skor yang diperoleh dengan menjumlahkan skor dari masing-masing validator.

3) Menentukan persentase kepraktisan: 
Kimia Berbasis Blog pada Materi Hidrokarbon

$$
\text { Persentase }=\frac{\text { Skor yang diperoleh }}{\text { Skor maksimal ideal }} \times 100 \%
$$

Hasil persentase kevalidan kemudian ditafsirkan dalam pengertian kualitatif berdasarkan pada tabel berikut ini.

Tabel 2. Kriteria Penilaian Uji Validitas E-modul

\begin{tabular}{|c|c|c|}
\hline No. & Interval & Kriteria \\
\hline 1 & $81 \%-100 \%$ & Sangat Valid \\
\hline 2 & $61 \%-80 \%$ & Valid \\
\hline 3 & $41 \%-60 \%$ & Cukup Valid \\
\hline 4 & $21 \%-40 \%$ & Kurang Valid \\
\hline 5 & $0-20 \%$ & Tidak Valid \\
\hline
\end{tabular}

Hasil persentase kepraktisan kemudian ditafsirkan dalam pengertian kualitatif berdasarkan pada tabel berikut ini.

Tabel 3. Kriteria Penilaian Uji Praktikalitas Emodul

\begin{tabular}{|c|c|c|}
\hline No. & Interval & Kriteria \\
\hline 1 & $81 \%-100 \%$ & Sangat Praktis \\
\hline 2 & $61 \%-80 \%$ & Praktis \\
\hline 3 & $41 \%-60 \%$ & Cukup Praktis \\
\hline 4 & $21 \%-40 \%$ & Kurang Praktis \\
\hline 5 & $0-20 \%$ & Tidak Praktis \\
\hline
\end{tabular}

Hasil persentase kepraktisan kemudian ditafsirkan dalam pengertian kualitatif berdasarkan pada tabel berikut ini.

Tabel 4. Kriteria Penilaian Respon Siswa Terhadap E-modul

\begin{tabular}{|c|c|c|}
\hline No. & Interval & Kriteria \\
\hline 1 & $81 \%-100 \%$ & Sangat baik \\
\hline 2 & $61 \%-80 \%$ & Baik \\
\hline 3 & $41 \%-60 \%$ & Cukup baik \\
\hline 4 & $21 \%-40 \%$ & Kurang baik \\
\hline 5 & $0-20 \%$ & Tidak baik \\
\hline
\end{tabular}

\section{HASIL DAN PEMBAHASAN}

Penelitian ini menghasilkan suatu produk berupa e-modul pembelajaran kimia berbasis blog pada materi hidrokarbon. E-modul ini didesain oleh peneliti agar dapat menjadi sumber belajar alternatif yang dapat membantu siswa belajar kapanpun dan di manapun. Selain itu, e-modul pembelajaran kimia juga didesain agar dapat membantu guru dalam proses pembelajaran yang dapat mengubah pola pembelajaran yang berupa Teacher Centered menjadi Student Centered. Pengguna blog dalam pembelajaran bisa dijadikan media interaksi antara guru dan pakar (guru) antara guru dan siswa, antar siswa dan siswa yang berkaitan dengan materi Pendidikan (Mudasir, 2016).

Model yang digunakan dalam pengembangan ini adalah model pengembangan Borg \& Gall yang disederhanakan sesuai kebutuhan penelitian terdiri dari tahap penelitian dan pengumpulan informasi, tahap perencanaan, tahap pengembangan produk awal, tahap uji coba lapangan produk dalam skala kecil, dan revisi produk.

\subsection{Penelitian dan Pengumpulan Informasi}

Tahap penelitian dan pengumpulan informasi merupakan kegiatan pemilihan suatu produk pendidikan yang akan dihasilkan dengan mempertimbangkan apakah produk tersebut betul-betul penting dan dibutuhkan dalam pendidikan. Tahap penelitian dan pengumpulan informasi ini terdiri dari studi literatur dan survei lapangan. Studi literatur dilakukan untuk mengumpulkan berbagai informasi yang berhubungan dengan penelitian yang akan dilakukan yaitu mengenai e-modul pembelajaran kimia. Studi ini ditujukan untuk menemukan konsepkonsep atau landasan-landasan teoritis yang memperkuat produk e-modul pembelajaran 
Kimia Berbasis Blog pada Materi Hidrokarbon

kimia. Melalui studi literatur ini juga dikaji ruang lingkup, keluasan penggunaan, kondisi pendukung agar $e$-modul pembelajaran kimia dapat digunakan, serta keunggulan dan keterbatasannya.

Pada tahap selanjutnya dilakukan survei lapangan berguna untuk melengkapi literatur penelitian dalam memberikan dasar-dasar pengetahuan untuk mendesain suatu produk e-modul pembelajaran kimia. Survei lapangan yang dilakukan dengan mewawancarai guru kimia SMK Pekanbaru. Berdasarkan hasil wawancara diketahui bahwa sumber belajar kimia yang digunakan siswa adalah buku teks pelajaran kimia. Ketersediaan buku teks pelajaran kimia yang terbatas dan dengan sistem rolling ke setiap kelas mengharuskan siswa menggunakan buku teks pada saat pembelajaran kimia saja. Sehingga siswa kurang memahami materi pelajaran yang disampaikan. Oleh karena itu diperlukan sumber belajar alternatif yang mudah diperoleh, mudah dimengerti dan menarik minat pembaca seperti modul elektronik ( $e$ modul). Pembelajaran dengan e-modul dapat dilakukan melalui aplikasi web berupa blogger.com, sehingga siswa dapat dengan mudah menggunakan e-modul ini sebagai sumber belajar mandiri yang dapat digunakan sewaktu-waktu tanpa dibatasi ruang dan waktu.

\subsection{Tahap Perencanaan}

Modul dirancang berdasarkan hasil analisis pada tahap penelitian dan pengumpulan informasi. Ada beberapa hal yang dilakukan pada tahap perencanaan, yaitu menentukan judul-judul modul, yang ditentukan ditentukan berdasarkan Kompetensi Dasar atau materi pembelajaran yang terdapat dalam silabus. Penulisan modul dilakukan dengan menggunakan software Microsoft Word 2010 dan Chemsketch, diunggah menggunakan aplikasi web berupa blogger.com dengan menggunakan berbagai variasi warna dan jenis tulisan. Jenis tulisan yang digunakan, diantaranya: Forte, Cooper Black, Times New Roman, Calibri, Ravie, dengan skala spasi 1,15 .

Materi pada e-modul pembelajaran kimia ini disusun berdasarkan kompetensi dasar dan tujuan pembelajaran yang akan dicapai. Penyusunan materi pada e-modul menggunakan beberapa buku kimia perguruan tinggi dan buku kimia SMK/MAK yang relevan. Alat evaluasi dalam e-modul pembelajaran kimia ini berupa latihan soal pada setiap akhir kegiatan pembelajaran dan soal evaluasi pada akhir materi hidrokarbon. Selain itu, juga dilakukan penyusunan instrumen-instrumen yang diperlukan selama penelitian, berupa angket uji validitas ahli materi pembelajaran, angket uji validitas ahli media pembelajaran, angket uji praktikalitas oleh guru, dan angket respon siswa.

Penyusunan kerangka e-modul pembelajaran kimia dilakukan sesuai dengan komponen penyusunan modul. Adapun bagian-bagian emodul yang akan dikembangkan yaitu cover/home, kata pengantar, petunjuk penggunaan e-modul, kompetensi inti, kompetensi dasar, indikator, tujuan pembelajaran, peta konsep, materi, evaluasi, glosarium dan daftar pustaka.

\subsection{Pengembangan Produk Awal}

Tahap pengembangan merupakan tahap mengembangkan bentuk modul yang telah dirancang untuk dapat diuji cobakan di lapangan. Pada e-modul pembelajaran kimia terdapat beberapa komponen modul, diantaranya home/cover, kata pengantar, petunjuk penggunaan e-modul, Kompetensi Inti (KI), Kompetensi Dasar (KD), indikator, tujuan pembelajaran, peta konsep, uraian materi hidrokarbon, evaluasi, glosarium, dan daftar pustaka. Cover pada e-modul 

Hidrokarbon

pembelajaran kimia dapat dilihat pada gambar 1.

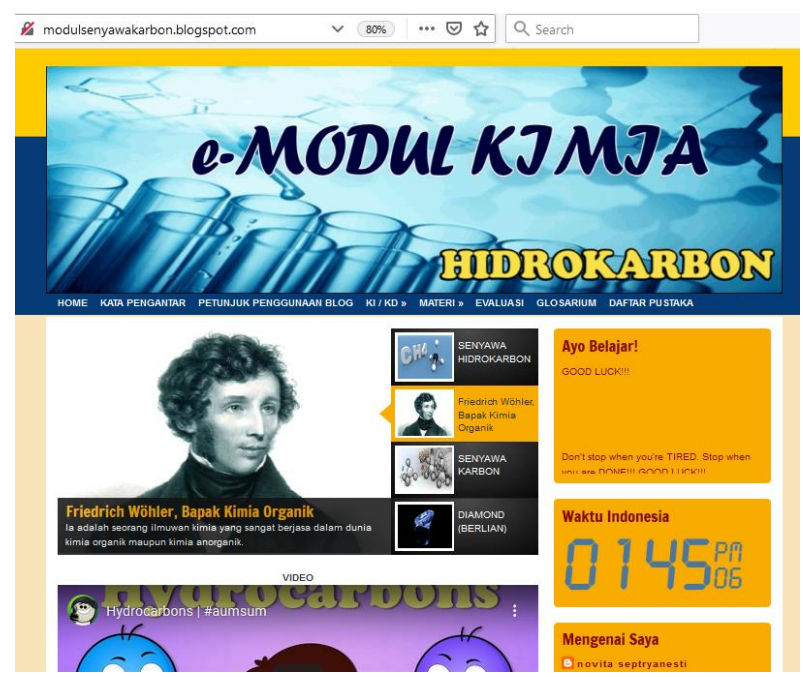

\section{Gambar 1. Cover e-modul}

Materi hidrokarbon, berisi pemaparan materi hidrokarbon, contoh soal dan latihan setiap akhir pembelajaran. Materi hidrokarbon terdiri dari 4 judul submateri, diantaranya: a) pengenalan senyawa hidrokarbon, b) hidrokarbon, c) keisomeran hidrokarbon, d) sifat-sifat fisis, sumber dan kegunaan hidrokarbon.

\section{Pembelajaran 1}

BY NOUTA SEPTRYANESTIDI 10.40 . OKOMENTAR

\section{PEMBELAJARAN 1}

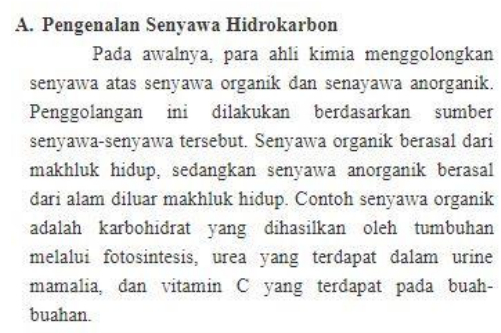
senyawa atas senyawa organik dan senayawa anorganik. Penggolangan ini dilakukan berdasarkan sumber senyawa-senyawa tersebut. Senyawa organik berasal dari makhluk hidup, sedangkan senyawa anorganik berasal dari alam diluar makhluk hidup. Contoh senvawa organik adalah karbohidrat yang dihasilkan oleh tumbuhan melalui fotosintesis, urea yang terdapat dalam urine mamalia, dan vitamin $\mathrm{C}$ yang terdapat pada buahbuahan.

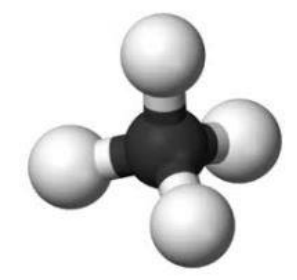

Pada tahun 1828 , frederich wohler, seorang ahli kimia berkebangsaan jerman, mengumumkan bahwa ia telah berhasil membuat urea tanpa ginjal mamalia. Wohler menghasilkan senyawa ini melalui pemanasan amonium sianat dengan reaksi sebagai berikut :

$$
\underset{\text { Amonium sianat }}{\mathrm{NH}_{4} \mathrm{CNO} \stackrel{\text { Pemanasan }}{\longrightarrow}} \underset{\text { Urea }}{\mathrm{CO}\left(\mathrm{NH}_{2}\right)_{2}+\mathrm{H}_{2} \mathrm{O}}
$$

Dari percobaan wohler ini, senyawa organilk urea dapat dibuat dilaboratorium.

\section{Gambar 2. Pembelajaran 1}

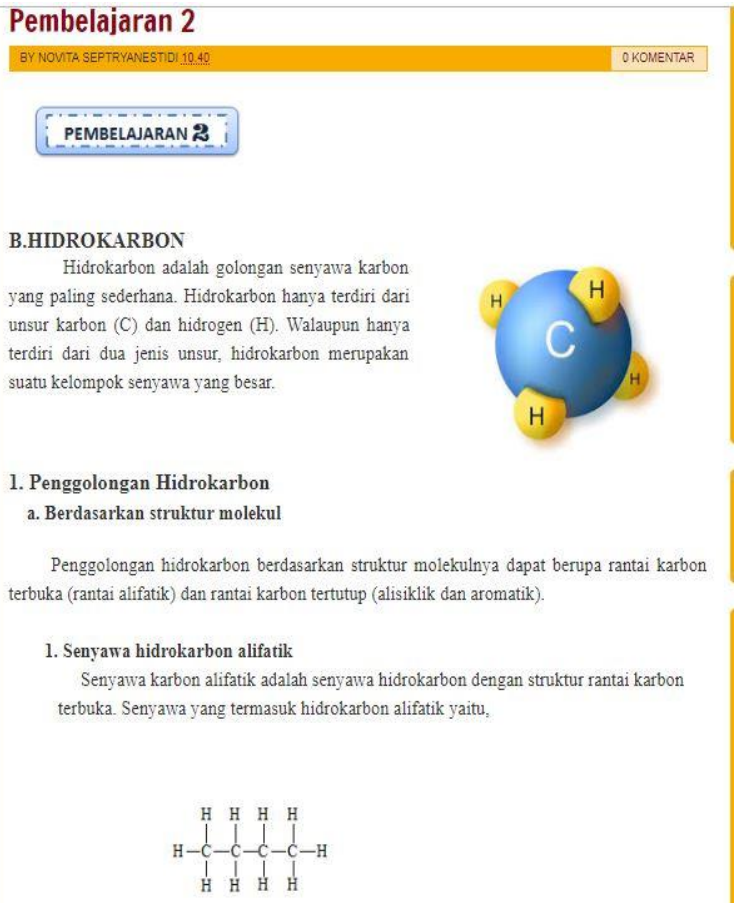

\section{Gambar 3. Pembelajaran 2}

\section{EVALUASI}

PETUNJUK : h satu jawaban yang paling tepa:

1. Salah satu faktor yang menyebabkan senyawa karbon 1 poir banyak jumlahnya adalah .... *
a. Karbon melimpah dikulit bumi
b. Karbon mempunyai 6 elektron valensi
c. Dapat membentuk rantai atom karbon
d. Titik didih karbon sangat tinggi
$\bigcirc$ e. Karbon sangat reaktif

2. Suatu senyawa alkana memiliki rumus struktur berikut! Berdasarkan struktur tersebut, atom $\mathrm{C}$ tersier ditunjukkan oleh atom $\mathrm{C}$ nomor .... *

$$
\mathrm{H}_{3}^{2} \mathrm{C}-\mathrm{CH}_{2}^{2}-\mathrm{CH}_{\mathrm{C}}^{\mathrm{C}}-\mathrm{CH}_{3} \mathrm{CH}_{2}-\mathrm{CH}_{\mathrm{C}}-\mathrm{CH}_{3}-\mathrm{CH}_{3}
$$

\section{Gambar 4. Evaluasi}

Sebelumnya dilakukan validasi terhadap instrumen yang akan digunakan sebagai alat untuk mengukur produk yang dikembangkan. Instrumen yang telah dirumuskan divalidasi oleh 2 dosen ahli instrumen. Proses validasi instrumen dilakukan sebanyak dua tahap, yaitu validasi instrumen awal dan validasi instrumen setelah revisi. Setelah instrumen yang akan digunakan valid dan layak digunakan untuk penelitian, tahap 
selanjutnya dilakukan validasi produk awal, antara lain:

\section{1) Validasi Oleh Ahli Materi Pembelajaran} Validasi ahli materi bertujuan untuk menilai kesesuaian materi dengan kompetensi, kesesuaian fitur dengan materi, penyajian dan komponen kebahasaan e-modul pembelajaran kimia. Validasi materi dilakukan oleh 2 dosen ahli materi. Proses validasi terhadap ahli materi dilakukan sebanyak dua kali yaitu validasi awal dan validasi setelah revisi.

Hasil validasi ahli materi I terhadap e-modul kimia yang didesain diperoleh aspek kesesuaian materi dengan kompetensi dengan nilai $100,0 \%$, aspek kesesuaian fitur dengan materi memperoleh nilai 90,0\%, penyajian dengan nilai $90,0 \%$ dan aspek kebahasaan memperoleh nilai 90,0\%. Sedangkan hasil validitas materi oleh ahli materi II diperoleh aspek kesesuaian materi dengan kompetensi dengan nilai 80,0\%, aspek kesesuaian fitur dengan materi memperoleh nilai $72,5 \%$, penyajian dengan nilai $75,0 \%$ dan aspek kebahasaan memperoleh nilai $86,7 \%$. Namun, karena ahli materi II memberikan saran dan komentar terhadap modul pembelajaran kimia perlu dilakukan revisi sesuai dengan komentar dan saran yang diberikan oleh ahli materi II. Adapun komentar dan saran dari ahli materi adalah dapat dilihat pada Tabel 5.

Tabel 5. Komentar dan Saran Ahli Materi.

\begin{tabular}{|l|}
\hline \multicolumn{1}{|c|}{ Ahli Materi I } \\
\hline $\begin{array}{l}\text { Modul pembelajaran kimia layak diuji } \\
\text { cobakan di lapangan tanpa revisi. }\end{array}$ \\
\hline \multicolumn{1}{|c|}{ Ahli Materi II } \\
\hline $\begin{array}{l}\text { Perbaiki beberapa bagian pada materi } \\
\text { tatanama, sumber dan kegunaan serta soal } \\
\text { disesuaikan dengan indikator. }\end{array}$ \\
\hline
\end{tabular}

E-modul pembelajaran kimia kemudian direvisi dan berdasarkan hasil validasi setelah revisi. Persentase hasil validasi materi oleh kedua ahli materi dapat dilihat pada Tabel 6 .

Tabel 6. Hasil Validasi oleh Ahli Materi.

\begin{tabular}{|c|c|c|c|}
\hline No & Indikator & Persentase & Kriteria \\
\hline 1 & $\begin{array}{l}\text { Kesesuaian } \\
\text { materi dengan } \\
\text { kompetensi }\end{array}$ & $100,0 \%$ & $\begin{array}{c}\text { Sangat } \\
\text { valid }\end{array}$ \\
\hline 2 & $\begin{array}{l}\text { Kesesuaian fitur } \\
\text { dengan materi }\end{array}$ & $91,3 \%$ & $\begin{array}{c}\text { Sangat } \\
\text { valid }\end{array}$ \\
\hline 3 & Penyajian & $92,5 \%$ & $\begin{array}{c}\text { Sangat } \\
\text { valid }\end{array}$ \\
\hline 4 & $\begin{array}{l}\text { Komponen } \\
\text { kebahasaan }\end{array}$ & $95,0 \%$ & $\begin{array}{c}\text { Sangat } \\
\text { valid }\end{array}$ \\
\hline \multicolumn{2}{|r|}{ Rata-rata total } & $94,0 \%$ & $\begin{array}{c}\text { Sangat } \\
\text { valid }\end{array}$ \\
\hline
\end{tabular}

Berdasarkan hasil validasi setelah revisi oleh kedua ahli materi, maka diperoleh persentase rata-rata total sebesar $94,0 \%$ yang berarti bahwa e-modul pembelajaran kimia sangat valid.

\section{2) Validasi oleh Ahli Media}

Validasi oleh ahli media bertujuan untuk menilai kelayakan kegrafikan e-modul pembelajaran kimia berbasis blog. Validasi media dilakukan oleh 1 dosen ahli media. Proses penilaian dilakukan sebanyak dua kali yaitu validasi awal dan validasi setelah revisi.

Hasil penilaian modul pembelajaran kimia tahap pertama diperoleh nilai pada aspek panduan pemanfaatan sebesar $86,7 \%$, pada aspek tampilan fisik sebesar $45,0 \%$ dan pada aspek komponen media sebesar 54,0\% sehingga rata-rata persentase kegrafikan pada validasi tahap pertama sebesar $57,7 \%$ dengan kriteria cukup valid. Meskipun demikian masih ada komentar dan saran dari 
Kimia Berbasis Blog pada Materi Hidrokarbon

ahli media untuk perbaikan e-modul pembelajaran kimia. Adapun komentar dan saran dari dosen ahli media dapat dilihat pada Tabel 7.

Tabel 7. Komentar dan Saran Ahli Media.

\begin{tabular}{|c|}
\hline Ahli Media \\
\hline Perbaiki beberapa bagian tampilan blog dibuat \\
interaktif, ditambahkan contoh video sesuai \\
materi, dan kuis disinkronkan dengan email \\
dan dibuat lebih interaktif. \\
\hline
\end{tabular}

Tahap selanjutnya setelah dilakukan revisi sesuai dengan komentar dan saran dari validator kemudian dilakukan kembali validasi e-modul pembelajaran kimia. Hasil dari penilaian media oleh ahli media pada tahap kedua terhadap modul pembelajaran kimia berbasis blog dapat dilihat pada Tabel 8 .

Tabel 8. Hasil Validasi oleh Ahli Media.

\begin{tabular}{|c|l|c|c|}
\hline No & \multicolumn{1}{|c|}{ Aspek } & Persentase & Kriteria \\
\hline 1 & $\begin{array}{l}\text { Panduan } \\
\text { pemanfaatan }\end{array}$ & $93,3 \%$ & $\begin{array}{c}\text { Sangat } \\
\text { valid }\end{array}$ \\
\hline 2 & Tampilan fisik & $80,0 \%$ & $\begin{array}{c}\text { Sangat } \\
\text { valid }\end{array}$ \\
\hline 3 & $\begin{array}{l}\text { Komponen } \\
\text { media }\end{array}$ & $90,0 \%$ & $\begin{array}{c}\text { Sangat } \\
\text { valid }\end{array}$ \\
\hline \multicolumn{2}{|c|}{ Rata-rata total } & $87,0 \%$ & $\begin{array}{c}\text { Sangat } \\
\text { valid }\end{array}$ \\
\hline
\end{tabular}

Berdasarkan tabel hasil validasi oleh ahli media terhadap modul pembelajaran kimia, dapat dilihat bahwa rata-rata total nilai validasi dari ahli media sebesar $87,0 \%$ dengan kriteria sangat valid.

\section{3) Hasil Validasi oleh Ahli Media dan Ahli Materi}

Data hasil uji validitas secara keseluruhan terhadap pengembangan modul pembelajaran kimia berbasis blog dapat dilihat pada Tabel 9.
Tabel 9. Hasil Uji Validitas oleh Ahli Materi dan Ahli Media.

\begin{tabular}{|c|c|c|c|}
\hline No & Validasi & Persentase & Kriteria \\
\hline 1 & $\begin{array}{c}\text { Ahli } \\
\text { materi }\end{array}$ & $94,0 \%$ & $\begin{array}{c}\text { Sangat } \\
\text { valid }\end{array}$ \\
\hline 2 & $\begin{array}{c}\text { Ahli } \\
\text { media }\end{array}$ & $87,0 \%$ & $\begin{array}{c}\text { Sangat } \\
\text { valid }\end{array}$ \\
\hline \multicolumn{2}{|c|}{$\begin{array}{l}\text { Validasi } \\
\text { keseluruhan }\end{array}$} & $90,5 \%$ & $\begin{array}{c}\text { Sangat } \\
\text { valid }\end{array}$ \\
\hline
\end{tabular}

Berdasarkan tabel hasil uji validitas oleh ahli materi dan media secara keseluruhan diperoleh persentase sebesar 90,5\%. Hal ini menunjukkan bahwa aspek kesesuaian materi dengan kompetensi, kesesuaian fitur dengan materi, penyajian, komponen kebahasaan, panduan pemanfataan, tampilan fisik dan komponen media e-modul pembelajaran kimia berbasis blog pada materi hidrokarbon sangat valid dan layak digunakan untuk uji coba di lapangan.

\subsection{Uji Lapangan Produk Awal}

Uji lapangan produk awal bertujuan untuk melihat tingkat kepraktisan dan respon peserta didik terhadap e-modul pembelajaran kimia berbasis blog dari sisi pengguna baik guru maupun peserta didik karena berpraktik dalam situasi yang sesungguhnya baik keadaan, jumlah peserta didik, maupun sarana dan fasilitas pembelajarannya seluruhnya dalam keadaan nyata di sekolah.

\subsection{Uji Praktikalitas oleh Guru}

Uji praktikalitas bertujuan untuk menilai kepraktisan e-modul pembelajaran kimia melalui aspek kesesuaian materi dengan kompetensi, penyajian, komponen kebahasaan, kegrafikan. Uji praktikalitas dilakukan oleh guru kimia, karena mereka punya pengalaman dan wawasan praktik mengajar SMK.

Validator uji praktikalitas e-modul pembelajaran kimia berbasis blog terdiri dari 
2 orang guru kimia. Angket ini bertujuan untuk mengetahui tanggapan guru selaku praktisi terhadap e-modul pembelajaran kimia berbasis blog pada materi hidrokarbon. Uji praktikalitas dilakukan dengan memberikan e-modul pembelajaran kimia dan lembar angket uji praktikalitas kepada guru.

Hasil uji praktikalitas e-modul pembelajaran kimia berbasis blog oleh guru I diperoleh persentase rata-rata sebesar $98,9 \%$, guru II diperoleh persentase rata-rata sebesar $88,4 \%$ dengan kriteria sangat praktis. Adapun hasil dari uji praktikalitas yang dilakukan oleh kedua guru kimia terhadap e-modul pembelajaran kimia dapat dilihat pada Tabel 10.

Tabel 10. Hasil Uji Praktikalitas oleh Guru.

\begin{tabular}{|c|l|c|c|}
\hline No & \multicolumn{1}{|c|}{ Indikator } & Persentase & Kriteria \\
\hline 1 & $\begin{array}{l}\text { Kesesuaian } \\
\text { materi dengan } \\
\text { kompetensi }\end{array}$ & $100,0 \%$ & $\begin{array}{l}\text { Sangat } \\
\text { praktis }\end{array}$ \\
\hline 2 & Penyajian & $95,0 \%$ & $\begin{array}{l}\text { Sangat } \\
\text { praktis }\end{array}$ \\
\hline 3 & $\begin{array}{l}\text { Komponen } \\
\text { kebahasaan }\end{array}$ & $93,3 \%$ & $\begin{array}{l}\text { Sangat } \\
\text { praktis }\end{array}$ \\
\hline 4 & Kegrafikan & $95,7 \%$ & $\begin{array}{l}\text { Sangat } \\
\text { praktis }\end{array}$ \\
\hline \multicolumn{2}{|c|}{ Rata-rata total } & $95,2 \%$ & $\begin{array}{l}\text { Sangat } \\
\text { praktis }\end{array}$ \\
\hline
\end{tabular}

Berdasarkan tabel hasil uji praktikalitas oleh guru terhadap e-modul pembelajaran kimia diperoleh persentase rata-rata dari keempat guru adalah 95,2\% dengan kriteria sangat praktis. Hal ini berarti e-modul pembelajaran kimia berbasis blog layak diuji cobakan kepada peserta didik.

\subsection{Uji Respon Peserta Didik}

Tahap uji respon peserta didik terhadap $e$ modul bertujuan untuk melihat bagaimana respon peserta didik terhadap e-modul pembelajaran kimia berbasis blog yang didesain. Tahap ini melibatkan 10 orang peserta didik kelas XII TKJ 2. Data respon peserta didik terhadap e-modul pembelajaran kimia diperoleh dengan memberikan angket respon kepada peserta didik setelah mempelajari e-modul pembelajaran kimia mengerjakan soal evaluasi pada bagian akhir e-modul pembelajaran kimia. Hasil uji respon peserta didik terhadap e-modul pembelajaran kimia dapat dilihat pada tabel 11.

Tabel 11. Hasil Uji Respon Peserta Didik.

\begin{tabular}{|c|l|c|c|}
\hline No & \multicolumn{1}{|c|}{ Indikator } & Persentase & Kriteria \\
\hline 1 & Ketertarikan & $87,5 \%$ & $\begin{array}{c}\text { Sangat } \\
\text { Baik }\end{array}$ \\
\hline 2 & Isi & $84,0 \%$ & $\begin{array}{c}\text { Sangat } \\
\text { Baik }\end{array}$ \\
\hline 3 & Bahasa & $94,6 \%$ & $\begin{array}{c}\text { Sangat } \\
\text { Baik }\end{array}$ \\
\hline \multicolumn{2}{|c|}{ Rata-rata total } & $87,2 \%$ & $\begin{array}{c}\text { Sangat } \\
\text { Baik }\end{array}$ \\
\hline
\end{tabular}

\subsection{Revisi Produk Akhir}

Peneliti melakukan revisi akhir terhadap emodul pembelajaran kimia berdasarkan komentar dan saran hasil uji lapangan.

\section{1) Guru Kimia}

Pada angket uji praktikalitas yang diisi oleh guru terdapat komentar dan saran guru terhadap e-modul pembelajaran kimia. Adapun komentar dan saran yang diberikan oleh guru terhadap e-modul pembelajaran kimia dapat dilihat pada tabel 12 .

Tabel 12. Komentar dan Saran oleh Guru.

\begin{tabular}{|c|lr|}
\hline Validator & \multicolumn{1}{|c|}{ Kalidasi } \\
\hline \multirow{3}{*}{ Kuru I } & $\begin{array}{l}\text { e-modul berbasis blog ini sudah } \\
\text { layak untuk diujicobakan } \\
\text { dilapangan yang perlu } \\
\text { diperbanyak contoh, fakta dan } \\
\text { ilustrasi r sehingga siswa }\end{array}$ \\
\hline
\end{tabular}

Jurnal Tadris Kimiya 4, 2 (Desember 2019): 202-215

This is an open access article under CC-BY-SA license (https://creativecommons.org/licenses/by-sa/4.0/) 


\begin{tabular}{|c|l|}
\hline Validator & \multicolumn{1}{|c|}{$\begin{array}{c}\text { Validasi } \\
\text { Komentar dan Saran }\end{array}$} \\
\hline & bertambah paham lagi. \\
\hline Guru II & $\begin{array}{l}\text { e-modul kimia layak untuk } \\
\text { diujicobakan tanpa revisi. }\end{array}$ \\
\hline
\end{tabular}

Berdasarkan komentar dan saran yang diberikan oleh guru kimia SMK, modul yang dikembangkan sudah layak dan praktis. Namun, ada perbaikan menurut komentar dan saran guru II kemudian direvisi sesuai dengan saran dan masukan guru untuk menghasilkan modul yang lebih baik sehingga dapat di uji cobakan kepada peserta didik.

\section{2) Peserta Didik}

Berdasarkan angket respon peserta didik diperoleh beberapa saran untuk perbaikan modul yang dikembangkan. Adapun komentar dan saran peserta didik terhadap modul pembelajaran kimia dapat dilihat pada tabel

13.

Tabel 13. Komentar dan Saran Peserta Didik.

\begin{tabular}{|c|c|l|}
\hline No. & Aspek & \multicolumn{1}{|c|}{ Komentar dan Saran } \\
\hline 1 & Ketertarikan & $\begin{array}{l}\text { - Pelajaran yang } \\
\text { menyenangkan, } \text { - } \\
\text { modul nya bagus. } \\
\text { - Modulnya sangat baik, } \\
\text { saya dapat memahami } \\
\text { materi dengan modul. }\end{array}$ \\
\hline 2 & Aspek & Kenyajian \\
blog & $\begin{array}{l}\text { Modulnya cukup bagus, } \\
\text { tetapi pada saat ke } \\
\text { evaluasi kalau bisa masuk } \\
\text { ke materi tanpa } \\
\text { memasukan data diri } \\
\text { lagi jika masuk kembali } \\
\text { ke menu evaluasi. }\end{array}$ \\
\hline
\end{tabular}

E-modul pembelajaran kimia ini disusun berdasarkan kompetensi inti, kompetensi dasar, dan indikator pencapaian yang terdapat dalam kurikulum 2013 revisi. Penelitian ini menggunakan model pengembangan Borg \& Gall dipilih karena prosedurnya jelas, sistematis, dan memiliki keleluasaan untuk tidak diterapkan semua (Utomo dkk., 2015). Alasan peneliti membatasi sampai tahap kelima adalah karena keterbatasan waktu penelitian dan hanya dikembangkan untuk satu sekolah. Tahapan penelitian Borg \& Gall yang dilakukan dalam penelitian ini telah dimodifikasi dan dibatasi hanya sampai tahap kelima. Adapun tahapan Model Borg \& Gall yang dilakukan pada penelitian ini yaitu penelitian dan pengumpulan informasi, perencanaan, pengembangan produk awal, uji lapangan produk awal, dan revisi produk berdasarkan uji coba produk awal.

Salah satu materi pokok kimia yang dianggap sulit adalah materi hidrokarbon. Materi ini membutuhkan pemahaman konsep yang kuat dan bersifat komprehensif (W. Sanjaya, 2013). Salah satu faktor yang menyebabkan siswa kurang memahami konsep materi karena ketersediaan buku teks pelajaran kimia yang terbatas. Dengan didesainnya $e-$ modul pembelajaran kimia berbasis blog pada materi hidrokarbon ini diharapkan siswa mampu memahami konsep materi karena siswa dapat dengan mudah menggunakan $e$ modul pembelajaran kimia ini sewaktu-waktu tanpa dibatasi ruang dan waktu.

Blog sebagai media pembelajaran mandiri dapat membantu siswa untuk mempelajari materi pelajaran kapanpun dan di manapun tanpa terbatas ruang dan waktu. Beberapa keuntungan menggunakan blog adalah: 1) biayanya murah, 2) praktis dan efisien waktu, 3) bahan bisa dipilih sesuai kebutuhan, 4) orang dapat mengakses kapan dan di mana saja (Sari dkk., 2014). 
Kimia Berbasis Blog pada Materi Hidrokarbon

Desain uji coba e-modul pembelajaran kimia mulanya diujicobakan kepada ahli materi untuk mengetahui apakah materi yang dikembangkan dalam media sudah sesuai atau masih perlu revisi. Setelah mendapatkan hasil uji coba dari ahli materi, kemudian media pembelajaran diujicobakan kepada ahli media untuk mengetahui apakah media yang dikembangkan sudah layak atau perlu revisi (Farenta dkk., 2016). Selain itu, Uji kepraktisan dilakukan untuk mengetahui tingkat kepraktisan media pembelajaran yang dikembangkan. Dalam penelitian ini, uji kepraktisan dilakukan melalui pemberian angket (Nasution dkk., 2016).

Berdasarkan hasil validitas e-modul pembelajaran kimia dinyatakan sangat valid jika dilihat dari aspek kesesuaian materi dengan kompetensi, kesesuaian fitur dengan materi, penyajian, kebahasaan, panduan pemanfaatan, tampilan fisik, dan komponen media. Dilihat dari aspek-aspek tersebut sesuai dengan penelitian sartono yang menyatakan bahwa guru dapat mengupload semua informasi yang berkaitan dengan materi pembelajaran yang diajarkan dengan menambahkan multimedia (gambar, animasi, efek suara, dan sebagainya) agar siswa lebih tertarik mempelajarinya (Sartono, 2016).

Secara keseluruhan hasil uji praktikalitas oleh guru terhadap e-modul pembelajaran kimia blog pada materi hidrokarbon dinyatakan praktis dan layak digunakan sebagai sumber belajar mandiri. Hal ini didukung dengan penelitian Haritsa Ulya yang menyatakan bahwa kepraktisan e-modul yang dikembangkan diukur berdasarkan kepraktisan tanggapan guru dengan kategori tinggi atau sangat tinggi (Ulya dkk., 2018).

Berdasarkan data hasil respon peserta didik yang diperoleh persentase $87,2 \%$ dengan kriteria sangat baik. Hal ini sejalan dengan penelitian Dwi Indah Suryani yang menyatakan bahwa kepraktisan e-modul pembelajaran yang dihasilkan dapat ditentukan berdasarkan banyaknya presentase siswa yang termasuk kategori praktis yaitu $>70 \%$ atau lebih (Herwati, 2016).

Hasil penelitian ini secara umum menunjukkan kelebihan e-modul pembelajaran kimia berbasis blog pada materi hidrokarbon yang didesain peneliti memiliki kelebihan yaitu siswa dapat belajar secara mandiri di mana pun dan kapan pun tanpa terbatas ruang dan waktu. Hal ini sejalan dengan sartono yang menyatakan media pembelajaran melalui blog memiliki keuntungan, yaitu siswa dapat belajar materi lebih lengkap, waktu yang lebih lama dan tentunya suasana yang lebih menyenangkan. Siswa dapat belajar di mana pun dan kapan pun, yang tentunya berbeda dengan pembelajaran konvensional selama ini berupa tatap muka (Sartono, 2016).

\section{KESIMPULAN}

Berdasarkan hasil penelitian yang telah dilakukan, maka dapat disimpulkan bahwa produk yang dihasilkan berupa e-modul pembelajaran kimia berbasis blog pada materi hidrokarbon. Tingkat validitas $e$-modul dengan kriteria sangat valid, tingkat praktikalitas dengan kriteria sangat praktis, dan respon peserta didik terhadap e-modul sangat baik. 


\section{DAFTAR PUSTAKA}

Agustina, Erna., Agung Nugroho dan Sri Mulyani. (2013). Penggunaan Metode Pembelajaran Jigsaw Berbantuan Handout Untuk Meningkatkan Aktivitas Dan Prestasi Belajar Siswa Pada Materi Pokok Hidrokarbon Kelas XC SMA Negeri 1 Gubug Tahun Ajaran Pada Materi Pokok Hidrokarbon Kelas XC SMA Negeri 1 Gubug Tahun Ajaran 2012/2013, Jurnal Pendidikan Kimia (JPK), 2(4), 66.

Farenta, Arvi Sekar., Sulton, Punaji Setyosari. (2016). Pengembangan E-Module Berbasis Problem Based Learning Mata Pelajaran Kimia Untuk Siswa Kelas X SMA Negeri 8 Malang, Jurnal Pendidikan: Teori, Penelitian Dan Pengembangan, 1(6), 1160.

Herwati. (2016). Pengembangan Modul Keanekaragaman Aves sebagai Sumber Belajar Biologi, Jurnal Lentera Pendidikan LPPM UM METRO, 1(1), 2836.

Mudasir. (2016). Pembelajaran Berbasis Multimedia. Pekanbaru: Kreasi Edukasi.

Nasution, Syaiful Hamzah., Lathiful Anwar, Sudirman dan Susiswo. (2016). Pengembangan Media Pembelajaran Untuk Mendukung Kemampuan Penalaran Spasial Siswa Pada Topik Dimensi Tiga Kelas $\mathrm{X}$, JURNAL KIP, 4(2), 906.

Priyayi, Desy Fajar. (2016). Analisis Bahan Ajar Model Pembelajaran Alid (Accelerated Learning Included By Discovery) Pada Materi Jaringan Tumbuhan Kelas XI SMA N 7 Surakarta, Jurnal Pendidikan Sains, 04(01), 29.
Rahmi, Ayu., Yusrizal dan Ilham Maulana. (2014). Pengembangan Bahan Ajar modul pada Materi Hidrokarbon di SMA Negeri 11 Banda Aceh, Jurnal Pendidikan Sains Indonesia, 02(01), 13.

Riduwan. (2007). Skala Pengukuran VariabelVariabel Penelitian. Bandung: Alfabeta.

Sari, Ratna Almira., Sulistyo Saputro, Agung Nugroho Catur S. (2014). Pengembangan modul Pembelajaran Kimia Berbasis Blog Untuk Materi Struktur Atom Dan Sistem Periodik Unsur SMA Kelas $X$, Jurnal Pendidikan Kimia (JPK), 3(2), 8-14.

Sartono. (2016). Pemanfaatan Blog Sebagai Media Pembelajaran Alternatif di Sekolah, Jurnal Tranformatika Guru SMA Negeri 2, 123.

Sugiyono. (2014). Metode Penelitian Pendidikan: Pendekatan Kuantitatif, Kualitatif, dan $R \& D$. Bandung: Alfabeta.

Trianto. (2010). Pengantar Penelitian Pendidikan Bagi Pengembangan Profesi Kependidikan dan Tenaga Kependidikan. Jakarta: Kencana.

Ulya, Haritsah., Ratu Beta Rudibyani, Tasviri Efkar. (2018). Pengembangan Modul Kimia Berbasis Problem Solving Pada Materi Asam Basa Arrhenius, Jurnal Pendidikan dan Pembelajaran Kimia, 7(1), 136.

Utomo, Dedi Sasmito., Sumarmi, dan Singgih Susilo. (2015). Pengembangan Bahan Ajar e-learning Berbasis Edmodo Pada Materi Litosfer Kelas X SMA, Jurnal Pendidikan Geografi, 2. 
W. Sanjaya. (2013). Penelitian Pendidikan: Jenis, Metode dan Prosedur. Jakarta: Kencana.

Zulkarnain, Andi., Nina Kadaritna dan Lisa Tania. (2015). Pengembangan E-Modul Teori Atom Mekanika Kuantum Berbasis Web Dengan Pendekatan Saintifik, Jurnal Pendidikan dan Pembelajaran Kimia, 4(1), 224. 